\title{
Post-structuralism and the Trinity: A reading of The Brand New Testament
}

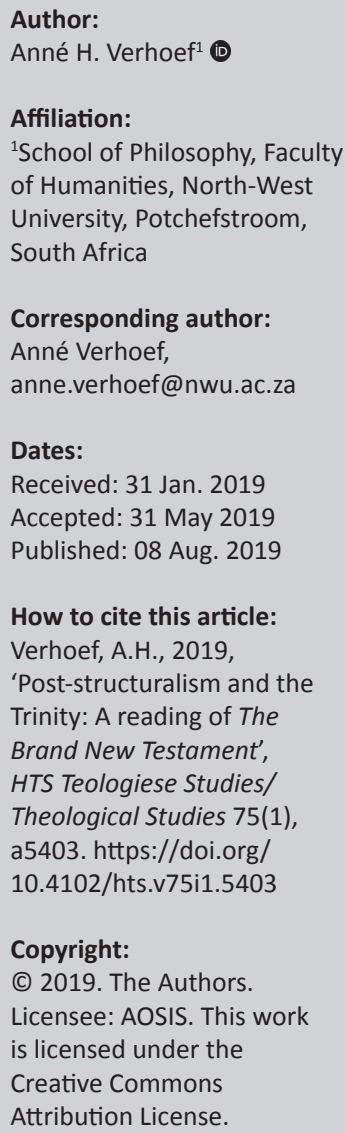

From a post-structuralist position, it is problematic and seemingly impossible to refer to God as the Trinity. This article describes possibilities for thinking about the Trinity (religion and God) within a post-structuralist context. As an example of such thinking, the 2015 culturecritique film, The Brand New Testament, will be analysed. It is a creative retelling of the Christian story and of the Trinity in a secular and post-metaphysical vein. This 'Brand New Testament' reveals God as 'one' - as the encompassing love, hope and life which we may experience in this life. The life-giving characteristics of this 'god' are surprisingly close to the biblical understanding of the Trinity. In the 'Brand New Testament', however, the Trinity is portrayed radically differently than in the Christian tradition. The personae of father, son and spirit are deconstructed in the film, in that a daughter and a mother also form part of the godhead. This deconstruction of the Trinity, which should not be confused with blasphemy, opens up a possible post-structuralist imagining of God. It playfully reveals a powerless god who shares some fundamental characteristics with the Trinity - such as love, joy and life. It allows for the 'oneness of god' to include more, and less, than the 'Holy Trinity'.

Keywords: Post-structuralism; Trinity; The Brand New Testament; Deconstruction; Faith; Belief; Theology; Philosophy of religion.

\section{Post-structuralism and the Trinity}

The Trinity is the 'most proper' naming of the absolute, the identity of the particular revelation of God within Christianity. 'Father, Son and Holy Spirit' is the specific Christian name for God, the 'historical particularity of God's identity' (Peters 1998:343), the 'traditional faith expression' (Bentley 2017:6) in Christianity or as the Trinitarian theologian Robert Jenson says, the Trinity is 'a maximally compressed version of the one God's particular story' (2010:35). ${ }^{1}$

The Trinity is fundamentally part of the 'historical resources' of Christianity, without which philosophical theology run the risk of 'becoming empty' (Gregersen 2013:417). The philosopher Richard Kearney identifies this risk in his reaction to the critique of post-structuralism ${ }^{2}$ that God is the 'infinite desertification of language' (Derrida 1995:55-56; Meylahn 2016:4), unknowable and unnameable. Kearney consequently asks, 'does deconstructive 'faith' not risk becoming so empty that it loses faith in the here and now altogether?' (2010:64). The critique of post-structuralism cannot be ignored either, because one may thereby lapse into a sort of post-modern fideism and 'apathetic pluralism' (Schrijvers 2016:4). How are we then to think about the critique and implications of post-structuralism and the particularity and naming of the Trinity?

Many theologians and philosophers have engaged with these questions for the past few decades and the aim of this article is not to repeat or summarise all their arguments. ${ }^{3}$ The focus here is on how the Trinity is deconstructed in The Brand New Testament and how it opens up different imaginings of God which might not be too far removed from the biblical description. It gives an

1.For Robert Jenson, God is Trinity because of God's involvement through history, through the father, son and spirit, which belongs
essentially to the life of the one God. The economic Trinity is the immanent Trinity. God is thus identified as Trinity through this
historical involvement, through 'his story', and it is not the outcome of some abstract debate regarding how three can be one or vice
versa (Verhoef 2008:235).
2.Poststructuralism and deconstruction is not understood here as synonyms. Deconstruction is positioned within the larger
poststructuralist movement which focuses on the gaps and ambiguities in the system of meaning. Poststructuralists find meaning in
these ambiguities, while deconstruction 'never overcomes the radical moment of ambiguating meaning' (Harcourt 2007:22). This
article follows Derrida's poststructuralist deconstruction as a starting point and moves then to the more 'positive' aspects of
poststructuralism.
3.For example, Graham Ward's 'Deconstructive Theology' in: Kevin J. Vanhoozer, editor, The Cambridge Companion to Postmodern
Theology (Cambridge: Cambridge University Press 2003), Lieven Boeve and Christophe Brabant's, Between Philosophy and Theology (Surrey: Ashgate 2010) and Frederiek Depoortere's, Christ in Postmodern Philosophy (London: T\&T Clark 2008).

Note: The collection entitled 'God as One', sub-edited by Erna Oliver (University of South Africa) and Willem Oliver (University of South Africa). 
idea of how the Trinity can be thought of differently within the 'playfulness' of deconstruction.

Post-structuralism, especially developed in the deconstructionist theories of Jacques Derrida, posits that language is not a transparent medium that connects one directly with a 'truth' or 'reality' outside language, but that we remain in language as a structure or code. Wisse states that 'the starting point of deconstruction is that the real, the given, is unavailable, is always beyond what we know' (2010:68). All that we have is a 'trace': no finality is given in language about the final meaning, or about that which is signified by the signifier, so that language itself is always 'trapped' within this endless referencing (différance). ${ }^{4}$ Derrida famously argued that 'there is nothing outside the text [there is no outside-text; il n'y a pas de horst-text]' (1997:158). Thus, 'there is nothing outside of the text that one can have access to without language, which is not also text' (Meylahn 2012:1).

The emptying of meaning that différance names has a close proximity to allegory (Ward 2003:80) and negative theology, but it does not necessitate (or equates to) negative theology (Coward \& Foshay 1992; Meylahn 2016:4). The implication is that a deferral (referral, postponement) of meaning takes place, that naming is contentless, and that we have a 'bottomless collapse, of this endless desertification of language' (Derrida 1995:56-57). For John Caputo, the implication of this for religion is that religion is 'without religion' (1997:161-181), without commitment to or identification with any particular concrete religion or god.

Naming (1) god (e.g. as Trinity) is only possible in 'religious discourse', 'God-talk' or 'theopoetics', which admits not to logic (theologic), but to:

a poetics of what stirs within the name of God, within what 'we' call 'God'. Since these quasi-phenomenological forms of theopoetics never reach the stasis of a fundamental Absolute reality, one must acknowledge that religion is Vorstellungen all the way down! (Caputo 2014:52)

For Caputo (following Derrida's deconstruction), there is no Absolute ground to religion, so that we can only have a 'religion without religion', a theopoetcis. This boils down to a sort of contentless faith, a 'passion of non-savoir [not knowing], impassioning the desire for the impossible and the unforeseeable' (Caputo 1997:312). Caputo breaks with 'any such metaphysical Absolute and settles for feeling around in the dark for the underlying "events"' (2014:52). Theopoetics should, however, not only be negatively assessed.

Meylahn observes that it brings a 'vulnerable inconclusivity and an active expectant openness' (2012:8) and this might help theology 'to steer away from 'theopoetry' (absolute knowledge; fundamentalism) and 'theopolitics' (a battle of the gods) which is often found in metaphysical theology' (Verhoef 2017:177). It is challenging but not impossible to différer means both 'to defer' and 'to differ'. think about Christianity (Trinity) in this context, where the 'transcendental signifier' is lost, and to 'move out of sterile debates of endless deconstruction' (Schrijvers 2016:xi). It asks for a more playful approach to our beliefs, without discarding it altogether. Schrijvers argues in his recent book, Between faith and belief (2016), that one should dynamically 'move between faith and belief' without abandoning either.

\section{Deconstruction and living between faith and belief}

Critique to Caputo's 'religion without religion' is that it 'remains stuck in the religions it wants to overcome or otherwise do away with' (Schrijvers 2016:xv). In this formula, 'religion' remains even if it is 'without': religion without religion is an acknowledgment that faith (religion) is crucial for life, something inescapable, but this faith (religion) is without Absolute content (religion) and without beliefs. In this formula, faith remains connected to some content or beliefs and is a 'religion' not completely 'without' religion. Schrijvers argues that an immunisation of faith from belief is impossible, but that other practises, such as sports and excessive consumption, have 'taken the place of religion in contemporary society' (2016:xv). Atheists who want to do entirely 'without religion' (faith without beliefs) may therefore either lose faith altogether - 'a genuine loss of faith' (Schrijvers 2016:xv) with an indifference to all things escaping our finite lives - or be lurked into some other beliefs. Some theists who want 'religion with religion' (with the emphasis on absolute beliefs) rather than 'religion without religion' may fall prey to the power of a sovereignty, to a 'dictatorship of tradition' (Schrijvers 2016:xvi) where the horizon of life is exhausted by the horizon of religion. Caputo concludes that 'religion with religion ... will always turn out to be somebody's religion' (2012:342). This poses the problem of theopolitics (battle of gods) and of fideism, as mentioned above.

Caputo's solution to this dilemma of how much 'with/ without' of religion is needed is to opt for a 'weak religion'. It is 'weak' because we cannot name the god properly. Christianity (and per implication the Trinity) is for Caputo 'a name for a historical set of beliefs that is always but a historical construction (and therefore subject to change and deconstruction). Christianity is immersed in the deconstructive play of the traces, where what we are trying to name can only ever be named inappropriately' (Schrijvers 2016:133).

Consequently, there is no absolute, no name (e.g. 'Trinity') that lies outside the 'system of Christianity'. This makes it a 'weak' religion, or a religion 'without religion'. The 'religion' in this formula is then described as 'a vitalistic force' (Schrijvers 2016:133) that rages through our being as a 'weak force'. The religion is 'weak' because no absolutes can be named, no sovereign power is claimed and there is no dictatorship of religion. It comes down to a 'faith that can do (almost) without belief or at least one that assents to beliefs minimally' (Schrijvers 2016:136). This assertion fits into the 
postmodern rejection of an ultimate signifier or grand metanarrative. It allows for a deconstruction of the most central beliefs of Christianity, like the name 'Trinity' for God, without rejecting it completely. It deconstructs it in a playful manner to get a sense of 'what keeps us going', what 'directs us toward our futures' and of 'our questioning of our existence, hopes and desires' - our faith in life itself - which does not commit to ultimate answers (beliefs), but functions within the non-authoritative (weak) force of 'weak religion'.

While this notion of Caputo may seem very abstract and theoretical, different art forms in our contemporary culture have translated it into concrete and practical terms. The Brand New Testament is one such example which may be used to illustrate some implications of this post-structural reading of the Trinity, especially for thinking about 'God as ONE: The Holy Trinity' (the title of this special edition). I will then briefly return to the question of Schrijvers regarding the relation between faith and belief, and also explore Richard Kearney's concept of Anatheism in this movie's post-structural reading of the Trinity.

\section{The Trinity in The Brand New Testament}

Because post-structuralist deconstruction is a loaded and contested term, I will confine my understanding to Jean-Luc Nancy's description that 'to deconstruct means to take apart, to disassemble, to loosen the assembled structure in order to give some play to the possibility from which it emerged but which it, qua assembled structures, hides' (2008:148). This applies to the Trinity in The Brand New Testament. In the movie, God is not only father, son and Holy Spirit, but also has a wife and a 10-year-old daughter, Ea (the name for the Akkadian god of wisdom). Reference to the 'Trinity' here is not intended to be faithful to a certain religious tradition or text, but rather to deconstruct the 'assembled structure' and to create a playfulness to expose what is not said, what else should be said and what power structures are at play in what we say about the Trinity. It involves a 'deconstruction' of the Trinity and not a 'destruction', in an attempt to gain more insight into this concept.

The Brand New Testament was directed by the Belgian Jaco Van Dormael and released in 2015. ${ }^{5}$ It is described as a 'wickedly amusing religious satire' (Holden 2016:1), a 'clever spiritual comedy' and as 'cheerfully blasphemous' (Chang 2016:1). The film's creative retelling of the Christian story should not be dismissed as blasphemy. Hoffman (2015:1) argues that 'if you can get past the initial blasphemy you'll find a highly moral film' and that the film 'is a vision of optimism, of people being given the opportunity to help one another and doing it with tenderness'. The movie can be seen as a retelling of the Christian story - and specifically of the Trinity - that can challenge our interpretation of the more original version,

5.Van Dormael states in an interview about the film that he does not believe in God, but that there is something in common between religion and cinema, namely (and but that there is something in common between religion and cinema, namely (and
here he is quoting Deleuze) that they try to make you believe life could have a meaning (Preston 2016:1). very much as one would find in the Jewish Midrash tradition. For believers and non-believers alike, it may open up new positive ways of thinking about God (as a deconstructive reading of any text can do with regard to any concept). In The Brand New Testament, the reference to the Trinity takes place in a secularised context and society.

This speaks about a 'deep indebtedness' to Christian symbols and concepts which are still present in this society. The movie is embedded in the Christian tradition, but its postmodern philosophical approach to Christianity and the Trinity is not one of a 'deep commitment' with regard to the name itself or its authority.

Rather, these symbols 'give rise to thought' 6 without the pretention or aim (as mostly in theology) to be authoritative. In this 'weak' religion, authority is continuously questioned, but the concept of religion (or the name) is not completely abandoned. My discussion of the movie will focus on these aspects. Thus, an analysis will be given of how the reference to the Trinity, along with the deconstruction thereof, functions within a 'religion without religion' as presented within The Brand New Testament. The underlying objective will be to identify positive aspects for one's life's direction, fulfilment and meaning in a post-structuralist reading of the movie's presentation of the Trinity.

The plot of the film is quite simple. God, the father, lives in a Brussels high-rise building, where he spends most of his time at his computer devising new tortures for the human race. God's son, J.C., managed to escape earlier, but he was killed by the people he wanted to help. No mention is made up of the Holy Spirit, but in the movie, God's wife fulfils the role of this third person of the Trinity. She is not the only female member of the godhead: there is also a daughter in the family, Jesus's younger sister, Ea. The father, mother, son and daughter are thus a gendered balanced deconstructed presentation of the Trinity. The Trinity is deconstructed into a fourfold godhead where the Holy Spirit is replaced by God's wife and where a younger sister is added. Even more significant than this feminine balancing of God is the 'balancing' of God's power in the movie. God is normally portrayed as powerful, with his power connected to the person of the father as a creator, but the roles and powers are reversed in the movie. Here, God the father loses his power and the daughter Ea gains power, albeit not the same or absolute power. She has a vulnerable and exposed power, even a helplessness, typical of a 10-year-old girl.

In the beginning of the movie, Ea manages to send all people their time and date of death. This removes God's power as the provider of one's time of (life and) death, and consequently, people no longer fear him.

Suddenly, with the knowledge of their date of death, everybody is confronted with what to do with the rest of their

6. Here, i follow the thoughts of Ricoeur. In Westphal's (2008:115) discussion of Ricoeur's hermeneutical phenomenology of religion, he says that, 'the philosopher, as such, does not, but rather can be described, where the symbol gives rise to thought, as one deeply indebted to these texts but not deeply committed to them'. 
lives. ${ }^{7}$ Ea's next move is to escape from the household to continue her brother's work. Her mission includes recruiting six apostles. The rest of the story centres on her mission and how six ordinary contemporary persons become her apostles. The apostles do not actually follow her, but this was not her intention either. Nevertheless, after Ea met these people, their lives change for the better. They have profound lifechanging experiences and become able to live meaningful lives despite their knowledge of when they would die.

In meeting the six apostles, the 10-year-old Ea does not represent a powerful authoritative God, but still manages to create some meaning and fulfilment for them. Ea's actions illustrate how meaning and fulfilment may still be created within the powerlessness of a 'religion without religion' and an absence of religious authority. Ea does not represent 'without religion' (because she remains part of the 'Trinity') but she does not represent 'religion' in the dogmatic authoritative sense either. The way in which she manages to change peoples' lives for the better illustrates the potential of (and need for) a 'religion without religion' as directional and meaningful for life. Ea's actions and the apostles' reactions form part of the movie's post-structuralist reading and representation of the Trinity. The Trinity is not deconstructed to a point of meaninglessness - this would be destruction. Instead, it is reimagined as a powerless, gender-neutral 'god' whose life-giving potencies and caring or loving relations are recognised, but reformulated. To explain this, an analysis is given of Ea's 'powerful powerless' interactions with the six apostles and their reactions.

\section{Ea's interaction with the six apostles}

It is clear from the beginning that all six apostles are missing something, either physically, emotionally or spiritually. They are not only intensely aware of their finitude (after receiving the date and time of their deaths) but are all trapped in some way. They are deeply in need of redemption. It is not primarily their finitude that is troublesome for them, but their entrapment, which prohibits them from living a fulfilled life here and now.

The changes Ea brings into their lives when they become apostles are not directed at an eternal life or a redemption from sin. She helps them to find fullness, meaning and happiness within this life, within their unique circumstances and for their unique needs. Ea's engagement with the six persons is not intended to change them to honour and praise a supernatural being or god. Ea is concerned with the apostles' own lives, their needs and their potential to celebrate life and love. In the movie, Jesus tells his sister Ea to pick the apostles randomly and to make their apostleship all about themselves. They must not become apostles of Ea, Jesus or God, but apostles of life itself - not in a narcissistic,

7.This is the crucial point on which the rest of the story centres, although it does not come across very strongly. The point is that God's power has been removed and that people no longer fear him. The more pertinent question for humans is now about their own existence and its meaning. The aspect of the death dates becomes a metaphor for contemporary society's lack of fear for God and the rejection of his metaphor for contemporary society's lack of fear for God and the rejection of his
(super)natural power. It thus introduces the existential questions of contemporary (super)natural pon
secular society. destructive and indulgent way, but in loving, sharing, appreciation and joy of life.

The randomly picked apostles represent major needs of humanity, particularly in modern secular West European society. These needs are, however, also universally applicable, and this illustrates Van Dormael's sharp diagnosis of the entrapments and emptiness of modern society. The six apostles' needs are telling of the typical burdens of modern people. These problems have become destructive to their lives and they cannot resolve them on their own, as becomes clear in an analysis of the apostles' individual stories.

\section{Aurelie}

The narrator describes Aurelie as a 'super nice girl' and 'the doormat of the whole building'. She is a beautiful but reclusive woman who lost her left arm as a child in a freak accident. Because of this, her life philosophy is: 'Life is like an ice rink ... a lot of people fall'. Life, for her, is to experience unavoidable, unexplainable pain, loss and suffering. Life is a risky place where one inevitably gets hurt. Her lost arm has become a symbol and constant reminder of this philosophy. Her loss and pain are not only physical, but she also has deep emotional scars which result in cynicism and sadness. She has not only lost her arm, but also her faith in the goodness and love of life. She is convinced that nobody will love her because of her physical and psychological loss. For her, there are only loneliness and pain left in this dangerous world. Like her right arm, she has no companion and she lives alone. She avoids the risk of love and life itself.

Upon discovering her death date, she decides to continue her life as before. Then Ea meets her and gives her a dream of her left-hand dancing on the table before her and eventually touching her right hand. This dream hints that life can be more than pain and loss. Life is not without pain and loss, but it is possible to find some comfort and healing in one's loss (as is illustrated by her left hand touching her right arm).

Aurelie changes after her dream, as she accepts that there might be more to life than pain and loss. This acceptance creates an openness and willingness for her to be loved and to take risks. When Francois, the fourth apostle, later tells her that he loves her, she manages to accept it, to believe it and to return his love.

When he kisses her prosthetic hand, it is a sign of his tender acceptance of life's loss, pain and risks. It is also a sign of his love for her that heals her loss, and of love's power to heal some of life's pains. Ea's intervention helps Aurelie realise that there is more in this world than pain, loss and suffering. Aurelie needed to see exactly this, even if it was just in a dream for a start.

\section{Jean-Claude}

The insurance worker Jean-Claude has lost his sense for adventure, his free spirit, his imagination, his gist and his 
freedom. He has traded the hours of his life for 'a shitty job with shitty hours'. He is trapped in his work and daily routine. As a child, he had a wild and adventurous imagination, but now his world has become very small: JeanClaude has climbed the corporate ladder, but he never lived his dreams and he got trapped in a monotonous, boring life.

When Jean-Claude learns the date of his death, he decides to sit on a bench in a park and never move from there. Here, Ea meets him and acts as an interpreter between him and a bird. Jean-Claude asks the bird why he stays in the park while he can fly anywhere in the world. The bird replies that he can ask the same of him.

Jean-Claude then experiences a dramatic conversion. He rises from the bench and starts to walk, following birds all over the world, to the Arctic Circle. His sense of adventure and his imagination are renewed and enjoyed. He lives his dreams. Ea sparked this by giving him an awareness of nature and birds and the freedom they enjoy. Ea thus helps him realise that life should not be reduced to something monotonous and boring. Nature, with all its freedom and splendour, reminds one of life's excitement and fullness.

\section{Marc}

Marc describes himself as a sex maniac. He is sexually frustrated, awkward with women and lovesick. He longs for his lost love, but this is only a fixation with a girl he had met on holiday as a child. Now he is trapped in this lovesick nostalgia, which has become a sexual obsession, with the result that he cannot meet the right woman and companion for him. True love is an impossibility in this life. Sex has now become a substitute and comfort, but it is such a dominant force that Marc became entrapped by it. In this process, life is reduced to sex and people are reduced to sex objects.

When Marc learns when he will die, he decides to spend his last days and all his money on prostitutes. He cannot get enough of sex. He imagines all women being naked and available - inevitably reduced to sex objects. Visiting prostitutes gives him only temporary relief, and he quickly spends more money on prostitutes than he initially planned. When Ea eventually meets him, he is broke. She tells him that he has a beautiful voice and that he should look for work. He manages to find work as a voice actor, ironically for pornographic movies. In this new working context, where sex is completely bereft of intimacy or meaning, he gets to know his female co-worker better on a personal level. They talk about things such as literature and joke about wrong sayings. In this hyper-sexualised context, sex ironically disappears, and Marc is able to see his co-worker as a human being. In a world full of sex, he sees the person herself and realises that there is more to life than sex. His co-worker turns out to be the girl on whom he became fixated as a child, but now he gets to know her as a person and not as a sex object. This leads to a fulfilling relationship, with meaningful and enjoyable sex. Sex remains part of this world, but so does the possibility of true love.
Marc's conversion to an apostle of Ea's takes place on different levels. His entrapment and his loss lay in his cynicism of true love, where he saw people (including himself) as sex objects and not as persons or human beings. His conversion as an apostle changes his perspective. He regains his belief in true love and becomes able to see others and himself differently. It all started with Ea's interventions when she admired a unique human quality about him: his voice. This helped him to think differently about himself and eventually also of others. His identity changed from a selfdeclared sex maniac to Marc, a person amongst other persons.

His conversion involves obtaining a more humane view of people. This leads to a fulfilled, meaningful and intimate relationship. All that Ea did was to make him aware of his unique human quality, his voice, so that he can see himself as human again. This helped him to see others as humans and to find his true love.

\section{Francois}

Francois, a life insurance salesman, is called the assassin. He always loved death. As a child, he never cried, was never sad and liked to kill ants, flies, butterflies, mice and birds. He says that to kill is his 'deep nature' and he even describes killing as his vocation. When he learns when he will die, he quits his job, buys a rifle and starts shooting at people, believing that he will only kill those who are meant to die anyway. He argues that he is 'merely the hand of destiny' and he is just the 'ferryman who helps people to cross the gap between life and death'. He therefore believes that there is nothing more to life than fate. His work as a life insurance salesman reinforces that belief. He experiences fate as an overwhelming force and has nothing to live for, to get excited about or even to cry about.

When Ea meets him, she challenges fate or destiny by telling him to shoot the next woman who crosses the bridge. This woman turns out to be the first apostle, Aurelie. The bullet hits her in her prosthetic arm, without her even noticing it. Francois is baffled by this incident and starts thinking that there might be something more to life than just fate. He follows Aurelie to her home and eventually realises what happened: this woman was first a victim of fate, but now also a survivor of it - twice now. This changes his own self-understanding and he realises that life is not mere fate but that he may take risks and even love people. He falls in love with Aurelie and eventually embraces his own image in the mirror.

Francois's conversion is from an understanding of life as fate, meaningless and empty, to embracing the wonders, mystery and surprises of life. He realises that there is more to life than fate. People live despite fate or as survivors of fate. Life is bigger than fate and might even include being loved and experiencing joy. When Aurelie later asks him later to stop shooting at people and he answers that he had lost interest in that, he implies that fate is not the major force in life, but that life itself is. He is free to love, despite fate. Ea brought about his conversion merely by challenging the power of fate. 


\section{Martine}

Martine is an elderly housewife trapped in a loveless marriage. Since childhood she has been predisposed to romantic love, but experiences only loneliness. She is rich and tries to compensate for her loneliness by shopping, getting spa treatments and even paying a young boy for sex. All this only increases her loneliness.

When Ea meets Martine, she takes her to the circus - not to have fun, but to help her recognise something of herself. At the circus, Martine sees a gorilla in a cage, also trapped, also lonely. This makes Martine to realise her own loneliness and captivity. As a result, Martine ('to get her house in order') takes action to escape her loneliness and captivity. She buys the gorilla from the circus and lets him live in her house. She sets him free so that she can be free. The gorilla gives her unconditional love and loyalty and takes away her loneliness.

He even scares away her disloyal husband. Martine's life is transformed from loneliness to fulfilment through Ea's intervention. Yet, Ea does not perform any miracle but only helps her see something of her need, so that Martine can take control of her own life, take responsibility and create her own happiness.

\section{Willy}

The last apostle, Willy, is a boy the same age as Ea. He has always been sickly. His mother is overprotective and has made him even more ill with all the medicine she gives him. When he learns that he only has a few days to live, he decides to live his last days as a girl. He was trapped in a gender identity that did not suit him. He wants to be free of all the expectations of being a boy. When Ea meets him, they talk about the destructive expectations parents have of their children. Willy concludes that 'we live in a totally shitty world' and Ea replies that it is her father's (God's) fault because he is power hungry, and that her mother (who is also a goddess) is silenced by her father. This is a clear critique of patriarchy and gender roles or identity.

The miracles Ea performs for Willy do not demonstrate power, but rather celebrate the simplicity of being human. She multiplies sandwiches for them to eat and also sends Willy a dream about a fish that wants to go back to the sea. The fish, just like Willy, longs for an environment where he can flourish, be free and live life in its fullness. Willy immediately understands that he needs this space, 'the sea'. His conversion firstly entails doing everything possible to get to the sea (e.g. selling all his parents' furniture). Then he and Ea decide to call every day a 'month' instead of a 'day'. In this way, he lives seven more months instead of 7 days - time gets relativised. Thirdly, he and Ea celebrate and enjoy every day together by listening music and dancing. Lastly, he discovers new abilities, like moving his hat towards his hand by only looking at it. The sickly, depressed Willy gets transformed into a joyful and powerful boy-girl. Again (as with Aurelie), Ea's main intervention is to help him understand his dream.
With Willy, there is an interesting role reversal. Ea, as God's daughter, is not omnipotent - for example, she cannot cry. Willy teaches her to 'cry', to love and to enjoy life. God, as Ea, learns from humans and receives joy and love from humans. Ea describes Willy as a miracle to her, because he is someone that teaches her of life and love.

\section{The life-giving potencies of a 'religion without religion'}

The six apostles' lives portray six existential challenges that can cause entrapment, suspicion and destruction in contemporary life. The first (Aurelie) is pain, suffering and loss - the unavoidable sadness of life. The second (JeanClaude) is the experience of being trapped in a boring daily routine with the loss of one's sense for adventure and imagination. The third (Marc) is the loss of love, with life being reduced to sex and people (including himself) being reduced to sex objects. The fourth (Francois) is the experience of fate as an overwhelming all-determining force. The fifth (Martine) is entrapment in a loveless relationship (marriage) and loneliness. The sixth (Willy) is entrapment in a gender identity (or other expectations of people) that does not suit one. All six apostles manage to overcome these deeply existential challenges with the help of Ea. She helps them find possibilities within this world and within themselves to love and live, and to 'overcome their natural impulses toward suspicion, hostility and violence' (Chang 2016:1). Ea inspires the apostles to change their lives for the better; to become apostles of life itself, so to speak. This 'cheerfully blasphemous movie' can therefore be described as a 'pointed hopeful vision of what life might be (with the right girl in charge)' (Chang 2016:1).

This girl is powerless, however. She represents the opposite of God the father in terms of age and gender.

She exercises her limited power by helping people to see things differently, by giving them dreams and by challenging their set conceptions of themselves and of life. As part of the 'Trinity', she seeks to empower people to live a full and meaningful life - one of happiness, love and joy. The question is whether there is anything religious or godly in Ea's intervention in these peoples' lives. In other words: Is Ea (and the Trinity she represents) representative of religion without religion?

The six apostles' conversions are clearly not conventional religious conversions in the sense of adopting a certain religion or denomination, or following a god or a person (Ea). Rather, they convert to life in its fullness. There remains something 'religious' in these 'non-religious religious' conversions, however, because of the religious context and narrative in which they take place. A new religious story is told - The Brand New Testament - which follows upon the foregoing testaments. The Christian symbolism, Ea's identity as part of the 'Trinity', the setting in Catholic Belgium and the scenes in the church all provide the religious context for the 
film in which these conversions take place. At the end, the apostles even form a new community that gather at the beach to read from the 'Brand New Testament'.

The format and tone of the story and conversions are religious, but absolute or traditional religious content or beliefs play no (or a minimal) role. No name or sovereign power is claimed, but some of the most central beliefs of Christianity are upheld, such as the belief in the goodness of life itself. Ea represents this vitalistic force and hopeful optimism for love and life. As part of the Trinity, she breaks down the absolute notion of it. The Trinity is only a symbol, only an entry point from where a fundamental and inclusive appreciation of life in its fullness is exposed, through the process of deconstruction. There is a post-structuralist reading of the 'Holy Trinity' in this movie, to arrive at the 'one god' of love, hope and life. It is a belief of minimal nature (a post-structuralist deconstructed 'Trinity'), but of huge importance for faith. Schrijvers (2016) emphasises the importance of both faith and belief. ${ }^{8}$

The Brand New Testament presents conversion narratives in a Christian context and reference frame, but without a Christian god and beliefs in this reference frame, these conversions are not 'Christian'. This begs the question whether Christian beliefs are the only criteria for 'Christian conversions' - and perhaps the movie confronts its viewers with exactly this question through its post-structuralist presentation of the Trinity. Is a life directed on the beauty, goodness, fullness and hopefulness of life not fundamentally similar to Christianity? Are there specific beliefs that must come into play, and what are they? On this point, The Brand New Testament challenges the concept of the Trinity and absolute beliefs. It is amplified by the fact that the movie has a playfulness and disregard for some of the most fundamental beliefs of Christianity. God is not good, but mean. He has a wife and a daughter. If certain beliefs are part of Christianity, what are they, and can (and should) they not be deconstructed to understand their underlying nature? Is this not a way of apprehending and comprehending the 'one god' in a more inclusive and even more 'Christian' way?

The movie brings into scope the contested nature of religious beliefs in general. The apostles' conversions are similar to religious conversions: spiritual, deeply private and inseparable from the emotional and psychological domains of existence. How, then, are religious conversions different? If it requires a reference to God, the movie would immediately put questions on the table such as: What god? Is God not perhaps the endless playful creativity, the power of love and life itself? One should therefore be open to a less dogmatic concept of God. This is the life-giving, optimistic, hopeful vision we find in the conversion narratives in the movie.

8.Schrijvers finds this minimal notion of belief in the ontological understanding of love as explicated in the work of Biswanger. This coresponds well with this article's as explicated in the work argument where Ea represents a fundamental, ontological vitalistic force that enables us to love and live - a love that confirms that we are not mere beings (as in Heidegger's ontology).

\section{Kearney's Anatheism}

The Catholic philosopher Richard Kearney's concept (and book) of Anatheism and the subtitle of this book, Returning to God after God, resonate with the conversion narratives of the apostles in the movie. Anatheism is a 'movement - not a state - that refuses all absolute talk about the absolute, negative or positive; for it acknowledges that the absolute can never be understood absolutely by any single person or religion' (Kearney 2010:16). Kearney explains that Anatheism is not atheism or theism, not anti-atheism or anti-theism, but a 'form of post-theism' (2010:57); 'amor mundi, love of the lifeworld as embodiment of infinity in the finite, of transcendence in immanence, of eschatology in the now' (2010:166). This amor mundi which Kearney describes has clear resemblance with the apostles' new found direction in their lives.

They find a strange 'god' after God - not the mean powerful god of Ea's father. Such a god is rejected by Kearney, who argues that we are 'free from the three-headed monster of metaphysics - the Omni-God of omnipotence, omniscience, and omnipresence - and the 'triumphalist teleologies and ideologies of power' that it has provoked' (Manoussakis 2006:xvi). All these 'omnies' are absent in Ea, the 10-year-old girl who is nonetheless part of the Trinity. It is the patriarchal power of God, the Trinity, that is firstly deconstructed in The Brand New Testament.

The second concept to be deconstructed is absolute beliefs about God. The six apostles in the movie do not use religious language or creeds to confess their new found faith. Their conversions rather involve graceful acceptance and celebration of the wonders of life. They accept an openness that there might be something more in life than pain, fate, loneliness and captivity. It is anatheistic in the sense that the 'God after God' is a 'source beyond and beneath oneself, a superfluity one does not possess or manipulate' (Kearney 2010:179), but the theistic element of ana-theism is radically reimagined and reconceptualised. Although the apostles do not use language of 'the sacred' or 'deep mystical' to describe their conversions, these remain profound experiences that lead to new appreciation of life and dramatic positive changes in their lives. They find hope, love and meaning on a very mundane, corporal and immanent level. In that sense, these conversions are examples of the life-giving potencies of a 'religion without a religion'. The answer to Kearney's question (in the beginning of this article), 'Does deconstructive 'faith' not risk becoming so empty that it loses faith in the here and now altogether?' (2010:64) is therefore negative.

Even if God is unknowable or unnameable, faith in life remains possible. Even in the context of endless deconstruction, there is a way of moving beyond the sterile debates, to find a more open and playful approach to beliefs which may provide a hopeful vision of life. With the transcendental signifier 'lost', everything is not lost. The poststructuralist deconstructed Trinity in The Brand New Testament is significant in this regard: although God cannot be named 
in absolute terms, the playful and imaginative identification of 'God' opens up possibilities of life, love and hope.

\section{Conclusion}

The Brand New Testament is a welcome contribution - very much in the Midrash Jewish tradition - of retelling the old Christian narratives to open some new and challenging perspectives, especially on the Trinity. The movie presents a post-structuralist imagining of the Trinity, which challenges absolute beliefs, patriarchy and power structures in religious symbols and concepts. It presents a 'religion without religion' without falling prey to the power of a sovereignty or the dictatorship of (religious) tradition.

While a deconstructive understanding of the Trinity may lead to a complete 'religion without religion', this movie presents a more positive and hopeful notion. It does not immunise faith from belief. It presents a 'religion without religion', but not an empty, meaningless religion. This religion has its own life-giving potencies. In the movie, the 'Trinity' is not understood as an absolute belief (religion) but neither is it rejected or ignored (without religion). The minimal belief it represents (religion without religion) plays a 'directional' and life-giving role. A total loss of faith in life, with a consequent indifference to all things that escape our finite lives, does therefore not occur. The movie acknowledges throughout that there is more to life than mere being and finiteness, and this needs to be discovered in various ways.

In this post-structuralist 'reading' of The Brand New Testament, the Trinity is deconstructed to the 'one god', as the encompassing love, hope and life which we may experience in this life. This powerless 'god' is playfully revealed as having the same fundamental characteristics like love, joy and life - as the (biblical) Trinity. It remains a 'religion without religion', but allows for the 'oneness of god' to include more, and less, than the 'Holy Trinity'.

\section{Acknowledgement}

\section{Competing interest}

The author has declared that no competing interests exist.

\section{Author contributions}

I declare that I am the sole author of this research article.

\section{Funding}

The author gratefully acknowledges the National Research Foundation for providing a research grant (No. 105930) for conducting this study.

\section{Data availability statement}

Data sharing is not applicable to this article as no new data were created or analysed in this study.

\section{Disclaimer}

The views and opinions expressed in this article are those of the authors and do not necessarily reflect the official policy or position of any affiliated agency of the authors.

\section{Ethical consideration}

This article followed all ethical standards for carrying out research without direct contact with human or animal subjects.

\section{References}

Bentley, W., 2017, 'How postmetaphysical can God-talk be?', HTS Teologiese Studies/ Theological Studies 73(3), a4669. https://doi.org/10.4102/hts.v73i3.4669

Caputo, J.D., 1997, The prayers and tears of Jacques Derrida: Religion without religion, Indiana University Press, Bloomington, IN.

Caputo, J.D., 2012, 'On not settling for an abridged edition of postmodernism. Radical hermeneutics as radical theology', in Simmons \& Minister (eds.), Reexamining deconstruction, pp. 271-353, 292-293, Duquesne University Press, Pittsburg, PA.

Caputo, J.D., 2014, 'Response by John D. Caputo: One slight tweak', in Crockett, Putt \& Robbins (eds.), The future of continental philosophy of religion, pp. 51-58, Indiana University Press, Bloomington, IN.

Chang, J., 2016, "Clever spiritual comedy "The Brand New Testament" finds God... in Brussels', Los Angeles Times, viewed 05 April 2018, from https://www.latimes. com/entertainment/movies/la-et-mn-brand-new-testament-review-20161205story.html.

Coward, H. \& Foshay, T. (eds.), 1992, Derrida and negative theology, SUNY Press, Albany, NY.

Derrida, J. 1995, 'Sauf le nom', in J. Derrida \& T. Duoit (eds.), On the name transl. D. Wood, J.J. Leavey \& I. McLeod, pp. 35-88, Stanford University Press, Stanford, CA.

Derrida, J., 1997, Of grammatology, transl. G.C. Spivak, John Hopkins, Baltimore, MD.

Gregersen, N.H., 2013, 'God, information and complexity: From descriptive to explorative metaphysics', Theology and Science 11(4), 394-423. https://doi.org/1 $0.1080 / 14746700.2013 .866475$

Harcourt, B.E., 2007, 'An answer to the question: "What is poststructuralism?"', Public Law \& Legal Theory Working Papers 156, 1-31. https://chicagounbound.uchicago. edu/public_law_and_legal_theory/30/.

Hoffman, J., 2015, 'The Brand New Testament review - God's not dead, just useless, in a sweet and blasphemous satire', The Guardian, viewed 05 April 2018, from https://www.theguardian.com/film/2015/may/19/the-brand-new-testamentreview-cannes-film-festival-2015.

Holden, S., 2016, 'Review: God is Alive and Crabby, according to "The Brand New Testament"', The New York Times, viewed 05 April 2018, from https://www. nytimes.com/2016/12/08/movies/the-brand-new-testament-review.html.

Jenson, R.W., 2010, 'How the world lost its story', First Things 201, 31-37.

Kearney, R., 2010, Anatheism: Returning to God after God, Columbia University Press, New York.

Manoussakis, J.P., 2006, After God: Richard Kearney and the religious turn in continental philosophy, Fordham University Press, New York.

Meylahn, J-A., 2012, 'Beyond categories, proper names, types and norms toward a fragile openness (Offen-barkeit) of différance, but always from within the text', HTS Theological Studies 68(1), 1-9. Art \#1003, https://doi.org/10.4102/hts. v68i1.1003.

Meylahn, J-A., 2016, 'Non-philosophical Christ-poetics beyond the mystical turn in conversation with continental philosophy of religion', HTS Teologiese Studies/ Theological Studies 72(3), a3542. http://doi.org/10.4102/hts.v72i3.3542

Nancy, J-L., 2008 [2005], Dis-enclosure: The deconstruction of Christianity, transl. B. Bergo, G. Malenfant \& M.B. Smith, Fordham University Press, New York.

Peters, T., 1998, 'God happens: The timeliness of the Triune God', The Christian Century 115(1), 342-344.

Preston, D., 2016, 'Jaco Van Dormael interview: "I hope that I never become God", Candid, viewed 05 April 2018, from https://candidmagazine.com/jaco-vandormael-interview/.

Schrijvers, J., 2016, Between faith and belief: Toward a contemporary phenomenology of religious life, SUNY Press, Albany.

Verhoef, A.H., 2008, 'How is Robert Jenson telling the story?' Scriptura 98, 231-243.

Verhoef, A.H., 2017, 'The relevance of continental philosophy of religion for theology in contemporary South Africa', Acta Theologica 37(2), 168-187. http://doi. in contemporary South Africa, Acta
org/10.18820/23099089/actat.v37i2.10

Ward, G., 2003, 'Deconstructive theology', in K.J. Vanhoozer (ed.), The Cambridge companion to postmodern theology, pp. 76-91, Cambridge University Press, Cambridge.

Westphal, M., 2008, 'Ricoeur's hermeneutical phenomenology of religion', in D.M Kaplan (ed.), Reading Ricoeur, pp. 109-127, SUNY Press, Albany.

Wisse, M., 2010, 'Introduction to the thinking of Graham Ward', in L. Boeve \& C. Brabant (eds.), Between philosophy and theology, pp. 65-72, Ashgate, Surrey. 